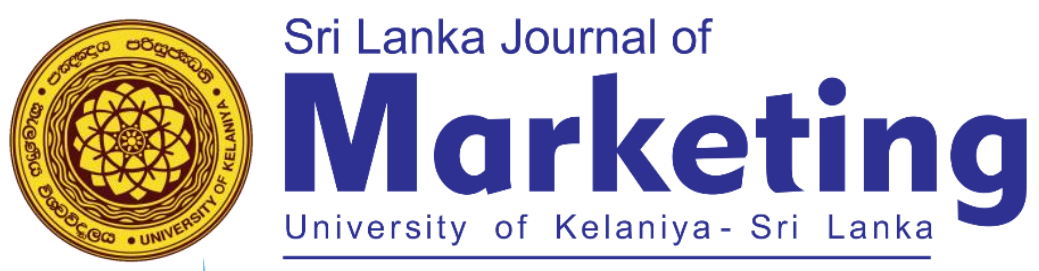

\title{
CSR Practices in the Maldives: A Post-Baseline Study
}

\author{
Mohamed Abdulla \\ National Institute of Education -Maldives \\ mohamedmeenaz@gmail.com
}

\section{ABSTRACT}

A baseline study on CSR was conducted in the Maldives in 2010 to understand the level of CSR engagement among the business community and non-corporate stakeholders of CSR promotion in the Maldives and develop recommendations for a CSR policy framework for the Maldives. The study revealed that CSR was understood in the Maldives in its surface level only. Philanthropic activities were the main CSR consideration and were not widely practiced. Only large public limited companies and the resorts maintain some mainstream CSR practices. This report highlights the progress made in CSR in the decade that followed the baseline study. The report was written based on the analysis of a three recent sustainability reports of the Maldivian resorts. A remarkable progress on ethical dimension and a minimal progress on philanthropic dimension were evident.

Keywords: CSR, Document Analysis, Maldives, Post-Baseline Study, Tourism Sector 


\section{INTRODUCTION:}

Businesses are basic economic units in the society (Carroll, 1979) without which the society members' needs and wants will not be fulfilled and their living standards will not be improved. Businesses are operated with the input provided by the society and utilizing the infrastructure and various aids to trade available within the society. The business output is the resultant of the societal input (Slack et al., 2010). The success of the output is the future of the business. Therefore, the more perfect the societal input is, the better for the effective and efficient operation of the business. Logically thought, as businesses depend such an extent to the society, it can be argued that the resultant effective and efficient operation of the business should provide a fair return, if not equal, to the society. Therefore, the businesses and society have a sort of symbiotic relation and need to work together for mutual benefits.

The trend of CSR has been changing over the time. In the Europe, government intervention in CSR is found to be minimal and CSR initiatives are driven by self-regulatory measures (https://www.csreurope.org/). While many companies rely on standard associations for self-regulatory CSR, some companies now started formulating their own standards for CSR. According to Millard (2017), Starbucks have developed their own in-house certification standard by taking examples from third party schemes. This indicates that the concept of CSR is a still evolving concept.

A decade ago, the baseline study on CSR in the Maldives revealed that CSR was understood in its surface level in the Maldives. The practices of CSR in the businesses, CSR coverage by the media, CSR coverage in the curriculum of educational institutions and research on CSR were very poor (Shareef \& Sodique, 2010). Therefore, the report recommended to make improvements in all these areas. Recently, the media seems to play a better role in promoting CSR. As such special webpages for CSR coverage appears in some websites such as https://www.bankofmaldives.com. and https://corporatemaldives.com. Based on the media coverage, it is evident that some public limited companies have been involved in huge CSR programs. However, no research has done after the baseline study focusing on the progress made on CSR in the Maldives. Therefore, this paper aim to address the following question by conducting a small-scale desk research; What is the progress of CSR in the Maldives after the baseline study that was conducted in 2010 ?

The paper is structured as follows: first, a review of literature on CSR will be presented followed by the methodology section and then the discussion which will consist the main findings of the baseline study, an analysis of the current CSR practices of corporations with the use of publicly available reports and a comparison of both of them. This will be followed by conclusion and future research direction. 


\section{LITERATURE REVIEW:}

The resultant reward or payback of business and community relation that is visible in the earliest literature and from the other various forms of evidences is philanthropic contribution from the businesses to the society (Carroll, 2018; Visser, 2006). In the earliest literature this had been regarded as social responsibility of businesses without the use of the term 'corporate'. According to Carroll (2018, p. 2), the term corporation had not been used as 'the age of the modern corporation's size, prominence, and dominance in the business sector had not yet been fully developed or been noted' then.

Therefore, the beginning of corporate social responsibility (CSR) could be the philanthropic aids given by the businesses to the society. According to Visser (2010), the history of Corporate Social Responsibility (CSR) could be traced back to 4000 years. Giving charitable donation is evident in the major religions (Visser, 2012) and charitable donations or philanthropic contribution is one of the domains of CSR identified in the Carroll's (1991) pyramid, which was later equated to corporate citizenship (Carroll, 1998).

In the USA, prior to 1900s, the philanthropic contributions of corporations were perceived negatively by many people believing that shareholders' money had been given away without their approval (Muirhead, 1999). During this era philanthropic aids were approved in ad hoc nature and the decision of such contributions had been mostly based as per executives' whim (ibid). In the beginning of philanthropic activities, they were mainly targeted to the Community/war chest, United Way Campaign, Boys Scouts, YCMA/YWCA, local hospitals, American Red Cross and local community chest (ibid). In the Maldivian context, the most common practice was providing philanthropic aids to individual's medical treatment and education, mosques and schools. There was a culture of keeping such philanthropic donations as unrevealed. Also the businesses did not have expectations or belief about any return for their social contribution (Shareef \& Sodique, 2010).

Started with philanthropic activity, the scope of CSR has been continuously evolving with demand and pressure from various stakeholders. Such demand and pressure had been raised for various reasons such as corporate accidents and scandals that resulted in loss of lives and wealth (Iatridis, 2011) and social cost of business activities such as visible environmental degradation. In the recent history, CSR has not only been driven by the direct demand from society. Rather, the driving forces of CSR in the modern days has been the 'business case for CSR'. In other words, the CSR has been institutionalized and embedded within the business strategies (Carroll, 2018). Therefore, CSR has become a very diverse topic.

The definition of CSR by different scholars, associations and businesses differ greatly. According to Carroll (1991), CSR “entails the simultaneous fulfilment of the firm's economic, legal, ethical and 
philanthropic responsibilities". The corporation "should strive to make profit, obey the law, be ethical, and be a good citizen". The definition of CSR by the European Commission (2001), is that it is "a concept whereby companies integrate social and environmental concerns in their business operations and in their interaction with their stakeholders on a voluntary basis." (European Commission, 2011). Visser (2011), defines CSR as "the way in which business consistently creates shared value in society through economic development, good governance, stakeholder responsiveness and environmental improvement".

Countless definitions and numerous terminologies for CSR has been used over the time (Carroll, 1999; Carroll, 2008). The term sustainability or sustainable practices is much more commonly used and advocated with respect to CSR nowadays. CSR Europe, The European Business Network for Corporate Sustainability and Responsibility, advocate for sustainable practices of businesses (www.csreurope.org, n.d.). The United Nations Global Compact also aims to promote sustainable and responsible business practices (www.unglobalcompact.org, n.d.). As such in the historic UN Summit held in September 2015, all Member States (193 Member States) adopted 17 Sustainable Development Goals (SDGs), broadly categorized into: (1) end all forms of poverty, (2) fight inequalities and injustice, and (3) protect the planet (tackle climate change), while ensuring that no one is left behind (https://www.unglobalcompact.org/sdgs/about). According to The United Nations Global Compact, these goals are applied universally to all countries and they need to mobilize efforts to achieve these goals by 2030. Visser (2017) argued that, some breakdowns or fragmentations are evident in the globe that hinders sustainability, and the SDGs is the world's best collected attempt to find a remedy for these breakdowns. He proposed an Integrated Value Web (a tool that is entirely consistent with SDGs' proposition) that can be used for testing meaningful innovative products/services to ensure sustainability (Visser, 2019). The following is the diagram of the Integrated Value Web proposed by Visser (2019): 


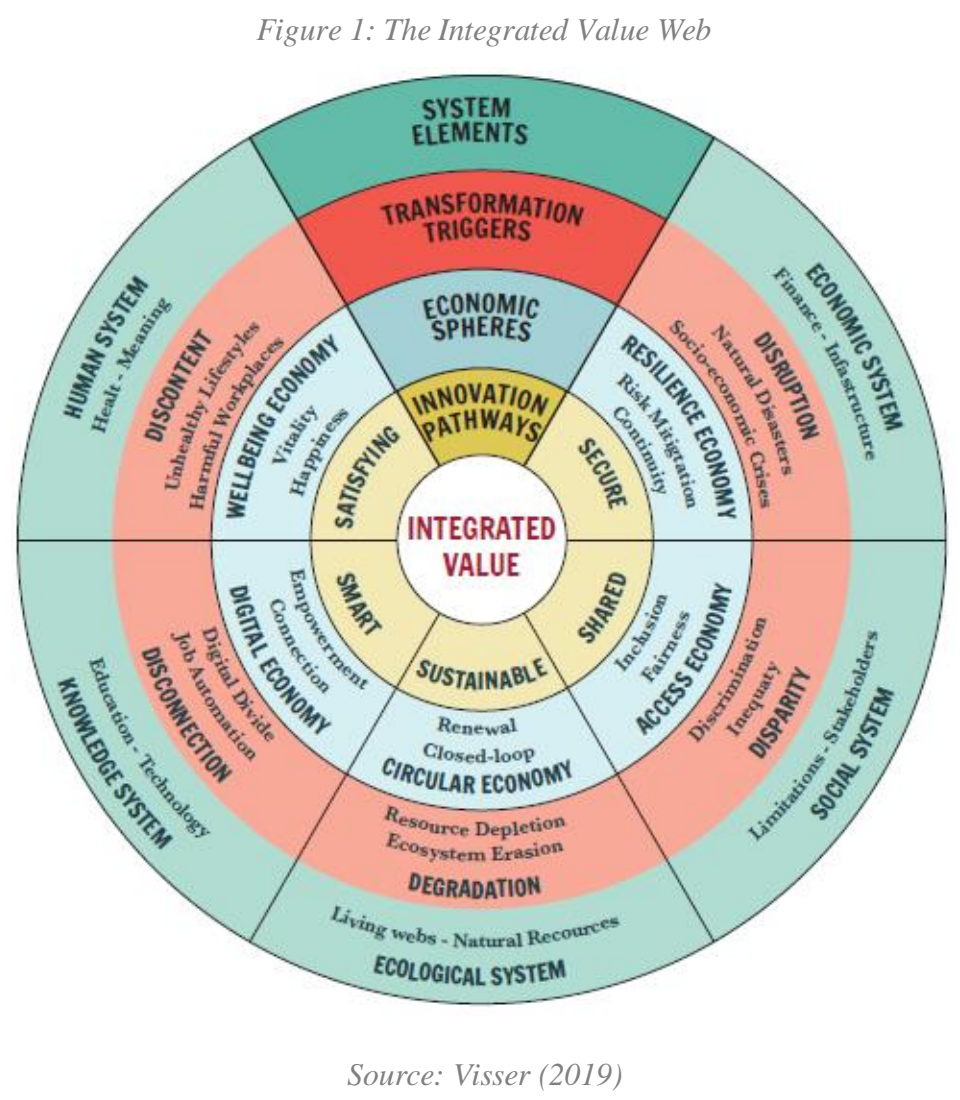

In the Maldives, until 2010, CSR was seldom heard and practiced. Followed by very first presidential election held under multi-party system, in 2010, a study initiated by the Maldivian government with collaboration from UNDP was done to understand the situation of CSR in the Maldives. The study was named as baseline study of CSR in the Maldives and aimed to understand "the level of CSR engagement among the business community and non-corporate stakeholders of CSR promotion in the Maldives, and develop recommendations for a CSR policy framework for the Maldives" (Shareef \& Sodique, 2010, p. 8).

The study revealed that the understanding of CSR was poor among the general people, media and the businesses as well (Shareef \& Sodique, 2010). CSR was a topic untouched in the education's institutions in the Maldives and in the research field CSR had not been taken into consideration in any means. The meaning of CSR in the Maldives was taken its surface level not only by the general people but the majority of the businesses as well. The only exceptional cases were the very large public companies and businesses operated in the tourism sector. The reasons why the tourism sector is better versed with the concept of CSR are (1) consumer demand (2) regulatory requirement (3) recognition and incentives (4) profitability and scale, and (5) international players (ibid). 


\section{METHODOLOGY:}

This paper aims to understand the current CSR practices of the Maldivian businesses by means of exploring the publicly available sustainability reports of corporations to understand specifically the changes occurred in the CSR practices since the baseline study. It could have been better to go for field research but the availability of limited time made the researcher to choose the alternative option of desk research. Since document analysis is one of the widely used technique in the qualitative research (Bryman \& Bell, 2015; Creswell \& Plano Clark, 2011), the researcher believes that this can serve the purpose of this paper.

The scope of this report is limited to the available resources from the web. The data search was done during mid-October 2020. It was found that CSR activities of small businesses are not publicly available. What publicly available was the reports of large public limited companies and companies operated in the tourism sector (tourist resorts only). The scope of this report therefore is limited to the tourist resorts of the Maldives only.

The data search resulted two sustainability reports of 2019 and four sustainability reports of 2018 . Among these six sustainability reports, the present study utilised the two sustainability reports of 2019 and a purposefully chosen sustainability report of 2018 based on the scope of the business activities. Various CSR activities conducted by these three resorts were identified from the reports and compiled in a sheet and analyzed to identify common focus and diversity of activities. These data were then compared with the findings of the baseline study of 2010 to draw a conclusion about the changes happened to CSR practices in the Maldives after the baseline study.

\section{DISCUSSION:}

\subsection{The Main Findings of the Baseline Study:}

The CSR in the Maldives prior to the baseline study was perceived as a 'one-way street', meaning that the sole role of businesses is giving without expecting or believing any return from it and the society is receiving. The perception in the Maldives then was 'that if something is expected or received in return (for example, providing better working conditions that result in higher productivity), it is out of the realm of CSR' (Shareef \& Sodique, 2010, p. 8).

Baseline study revealed that primary CSR focus of the tourism sector of the Maldives was environment protection. According to the report, there existed a huge gap between the CSR practices of resorts operated by the businesses under local ownership and international hotel chains (Shareef \& Sodique, 2010). While CSR practices were more fluid in local companies, international hotel chains were more systematic. The latter had written policies of CSR, adopted more formal CSR strategies, paid more 
attention to staff training and focused more on green resort concept. On the other hand, resorts under local ownership, tend to be managed by prominent individuals who also have political involvement, managed/handled more community projects (ibid).

Commonly practiced CSR activities of the business sector could be broadly categorized into:

(1) Environmental protection and conservation

- setting air-conditioner temperature at 24 degrees or higher

- replacing normal air-conditioner to inverter type and normal bulb to energy saving bulbs,

- recycle and minimize waste (example: reducing paper utilization).

- taking measures on pollution prevention, protection of natural environment and education and incentivizing employees on environmental protection.

(2) Employee welfare

- staff training (large companies only),

- preference to locals in staff recruitment

- staff recreational activities

- medical benefits and

- staff loans.

(3) Community participation

- assistance to individuals' medical treatment and education

- assistance to schools' and NGOs' events and

- participation in social events.

The baseline study on CSR in the Maldives identified a number of CSR activities conducted by businesses in the tourism sector. These activities were targeted generally to (1) recycling and minimise waste (2) conserve energy (3) protect natural environment (4) employee/guest health and safety (5) employee's welfare and (6) community participation (Shareef and Sodique, 2010).

(1) Specific programs conducted under "recycling and waste minimizing":

- Linen re-use programs to save energy and water and to minimize use of detergent

- Use of refillable glass bottles for water instead of disposable plastic bottles

- Treatment and re-use of waste water for gardening and flush tanks

- Compacting tin cans and bottles

- Use of glass crusher to dispose-off glass bottles

- Use of incinerator for general waste disposal

- Treatment of sewerage affluent (regulatory requirement) 
(2) Specific activities done to conserve energy were:

- Generate hot water from solar water heaters or from heat recovery from air-conditioners

- Outdoor and pathway lights connected to auto on-off timers

- Reminder notices to guests to switch off lights and appliances when leaving room

(3) Specific measures taken to protect natural environment were:

- Beach cleaning

- Banning of fishing on house reef and lagoon

- Tree plantation programs

- Minimize felling of coconut palms and trees

- Environmental assessment (regulatory requirement)

(4) Specific activities conducted under "health and safety" were:

- Food hygiene standards and protocols

- Fire safety system (regulatory requirement)

- Lightning protection

(5) Employee welfare programs included:

- Local employees to foreign employee ratio targets (regulatory requirement)

- Regular in-house staff training programs

- Staff recreation and sports

- Service charge and medical benefits

- Transportation arrangements to staff from nearby islands to visit home on off days

(6) Specific activities conducted for community were:

- Assistance for infrastructure development

- Assistance to island schools and health centers

- Volunteering of staff to mark special days on islands

- Tours arranged for the tourist to local islands to increase the sale of local products to the tourists.

\subsection{Main Findings of the Document Analysis:}

All the three resorts have been engaged in some activities to reduce energy consumption. One very commonly undertaken measure was changing bulb and tools and equipment to energy saving type. Two resorts have mentioned about utilization of solar power. One resort talked about the production of hot water using heat exchangers. All the resorts have taken measures to reduce Chlorofluorocarbons (CFC) while fixing of air-conditioner and refrigerators. Two resorts reported that they have taken remarkable measures in reducing single-use plastic. Of these include switching from plastic bottles to glass bottles 
in all the guest areas, use of paper straws instead of plastic ones, reduction in plastic bottle waste with glass self-bottling plant and reuse of dispenser gallons compacting of waste. Measures taken to conserve water are also significant in two resorts. These include preventive maintenance to prevent water leaks, reduction in the consumption of water, use of grey water and producing mineral water on site. One report has covered the procurement measures taken in order for waste reduction. These include consideration for less packaging, larger containers and also more recyclable packaging where packaging is absolutely necessary. Other than these when locally available things are being brought to the resort, plastic crates were used which will be taken back by the local supplier. Two resorts reported about going beyond the regulatory measures on managing sewage system. One resort maintains a state-ofthe-art sewage treatment plant. Both the resorts use the strategy of treating waste water organically and use them for gardening purposes. All the resorts pay attention to plant trees and maintain gardens. For this purpose, one resort reported that they import fertilizers from Sri Lanka. Two resorts maintain the in-house production and utilization of fertilizers by means of green wastes. Two resorts reported that they have been using environmentally friendly cleaning products and chemicals and one resort among them claimed that they dispose chemical waste materials sending them to Secure Bag, a licensed company for collection and recycling different types of waste. Although this is a common practice among the resorts in the Maldives, only one report mentioned about the utilization of electric bike. Two reports covered their efforts to preserve the coral reefs. One resort mentioned about the safely relocation of coral when jetty and breakwater were constructed. They also mentioned about an artificial reef set up made by them to help boost the growth of coral reefs. Another resort mentioned about the measures taken to proper mooring of boats to avoid damage by anchor. Although lagoon and beach cleaning are common among the resorts, only one resort reported these in their sustainability report. The same resort reported that they use barriers to protect sand (beach) erosion. Activities conducted along with staff and guests such as reef cleanups, tree planting, coral planting are done in monthly basis in two resorts and similar activities are being conducted in some resorts to celebrate special days such as environment day and earth hour. One resort was concerned about turtle preservation. One resort reported about a remarkable innovation while measure taken to reduce waste. They produce biogas as a by-product of organic waste and use them for cooking purpose. The same resort reported that they have in-house facilities for glass crusher, paper compactor and can crusher. Another resort reported that they use electronic waste management system. The same resort reported that they have a policy that addresses the re-use towel and linen. Although, it is a regulatory requirement to maintain local and expatriate employment ratio, only one resort reported about this. According to them, they think beyond the regulatory requirement in this respect. They claimed that $60 \%$ of their workforce are locals, and all have the opportunity to work their way up the ladder. They also claimed that the majority of their senior management team consisted of local employees. All of the three resorts have been engaged in some sort of local community program. One resort has been sustaining a co-sponsored plastic waste management 
program with Parley (a global collaboration network which addresses the global threat of marine plastic pollution) in a nearby island school. The same resort also has been sustaining the partnership with Parley to protect the marine environment and to manage plastic waste within the resort. The other two resorts claimed to have community relation by purchasing various productions and produces of the nearby island community. One of these resorts have been maintaining a remarkable community relation. They support the local community by purchasing fish directly from the fishermen, vegetables and fruits from nearby island once a week, cadjan that are required for roof thatching from local islands. They also donated some waste management equipment to nearby island and organized guest and staff excursions to a nearby island regularly, which help the local shops and restaurants to earn quite a big amount of money. Only one out of the three resorts mentioned about having a specific policy for printing. They also claimed to implement recycling of paper. The same resort also focused on noise pollution management. One resort had a research project on dolphin tracking to understand the movement patterns of the spinner dolphins. The same resort has been working in collaboration with Manta Trust and Olive Ridley project for manta rays and turtle conservation. Two resorts have mentioned about guests and staff awareness programs. Of these, one resort mentioned about screening of movies and documentaries such as chasing coral and BBC hunt as specific programs they conducted in this respect.

\subsection{Comparison of The Findings of Baseline Study and the Current Practice:}

Evidences of the economic responsibility of the Carroll's (1991) CSR pyramid are not visible in any report. This may be because the people who compiled the report might have considered irrelevant to include such a content in the sustainability report and preferred to include this information in the annual report.

Some measures taken on legal responsibility are evident. These included measures taken while constructing the resort such as coral relocating, avoidance cutting trees as much as possible. This was evident from the baseline study as well. Water management, waste management and sewage system management were also in accordance with the regulations. However, food standards have not discussed in the any report. Only one resort mentioned about the regulatory requirement of local and expatriate ratio. With respect to implementation of rules and regulation, this is one of the most questionable issues in the tourism sector. Human Rights Commission of the Maldives (2010) found that resorts had not been maintaining the required local and expatriate employee ratio. The researcher eye witnessed raising of the same issue in the very first CSR conference for tourism sector held in late 2019.

It is evident that all the resorts undertake several CSR activities beyond the regulatory measures. Carroll (1991) regarded this as ethical responsibility of businesses. In this respect, the tourism sector in the Maldives has achieved a remarkable progress compared to the situation before the baseline study. As can be seen from the findings, resorts have taken several advanced measures in waste management 
which are beyond the legal requirement. Also, some resorts have done remarkable efforts for the benefit of local community such as buying fish, vegetables and fruits and cadjan from nearby islands. While buying goods from the local community and from other suppliers, some resorts have taken remarkable measures to minimise the unnecessary packaging that will certainly minimise the cost and waste for both the parties.

The philanthropic responsibility of the Carroll's (1991) CSR model were most evident in the baseline study compared to other dimensions. Compared to the situation then, the current practice of the resorts in philanthropic contribution has a minimal progress. Most of the resorts have done collaborative activities with nearby islands in waste management.

\section{CONCLUSION:}

Based on the findings from the three-sustainability report, it can be concluded that CSR in the resort sector of the Maldives have progressed remarkably. It is most evident from the philanthropic contribution and ethical dimension of CSR. The progress of the other two dimension could not assess sufficiently as they have been not revealed in the reports adequately. These two dimensions may be assessed more thoroughly by other means of data collection such as interviews and questionnaires along with the document analysis.

\section{REFERENCES:}

[1]. Bryman, A. \& Bell, E. (2015) Business Research Methods. (4th ed.). Oxford: Oxford University Press.

[2]. Carroll, A. B. (1979). A three-dimensional conceptual model of corporate performance. Academy of management review, 4(4), 497-505.

[3]. Carroll, A. B. (1991). The Pyramid of Corporate Social Responsibility: Toward the Moral Management of the Organizational Stakeholders, Business Horizons (July - August 1991): 39-48.

[4]. Carroll, A. B. (1998). The fousr faces of corporate citizenship. Business and Society Review, $100(1), 1-7$.

[5]. Carroll, A.B. (2008). A History of Corporate Social Responsibility, In The Oxford Handbook of Corporate Social Responsibility, edited by Crane, McWilliams, Matten Moon \& Siegel, Oxford: OUP. 
[6]. Carroll, A. B. (2018). Corporate Social Responsibility (CSR) and Corporate Social Performance (CSP), in Kolb, R. W. (ed.), The SAGE Encyclopedia of Business Ethics and Society. Thousand Oaks: SAGE Publications, Inc.

[7]. Creswell, J. W. and Plano Clark, V. L. (2011) Designing and conducting mixed methods research. Second. Thousand Oaks, CA: SAGE Publications, Inc.

[8]. European Commission. (2011). Corporate social responsibility: a new definition, a new agenda for action. (MEMO/11/732, MEMO/11/734 and MEMO/11/735). European Commission, viewed 23 November 2020, <http://europa.eu/rapid/press-release_MEMO-11-730_en.htm>.

[9]. Human Right Commission of the Maldives (2009), Rapid assessment of the employment situation in the Maldives, Male' Maldives, Human Right Commission of the Maldives.

[10]. Iatridis, K. (2011) The Influence of Corporate Social Responsibility on Business Practice : The Case of International Certifiable Management Standards. PhD thesis. University of Central Lancashire.

[11]. Millard, E. (2017). Still brewing: Fostering sustainable coffee production. World Development Perspectives, 7-8, 32-42.

[12]. Muirhead, S. A. (1999). Corporate Contributions: The View from 50 Years. New York: The Conference Board.

[13]. Shareef, F. \& Sodique, H. (2010) Baseline Study on Corporate Social Responsibility Practices in Maldive. Male, Maldives: Ministry of Economic Development.

[14]. Slack, N., Chambers, S., \& Johnston R. (2010). Operations management. ( 6th ed.) United Kingdom: Pearson education limited.

[15]. Visser, W. (2006). Revisiting Carroll's CSR pyramid: An African perspective. In M. Huniche \& E. P. Rahbek (Eds.), Corporate citizenship in developing countries-new partnership perspectives (pp. 29-56). Copenhagen: Copenhagen Business School Press.

[16]. Visser, W. (2010). The world guide to CSR. UK: Greenleaf Publishing Limited.

[17]. Visser, W. (2011). The age of responsibility: CSR 2.0 and the new DNA of business. West Sussex: John Wiley \& Sons.

[18]. Visser, W. (2012). The future of CSR: Towards transformative CSR, or CSR 2.0. Kaleidoscope Futures Paper Series, 1, 1-17. 
[19]. Visser (2017) Integrated Value: What It Is, What It's Not and Why It's Important, viewed on 23 November $2020<$ https://www.huffpost.com/entry/integrated-value-what-it-is-what-its-not-andwhy_b_59cffdc3e4b0f58902e5ccbf>

[20]. Visser, W. (2019). Integrated value management: implementing sustainable transformation, AMS Sustainable Transformation Briefing Series, No. 5. Antwerp Management School. 
Appendix: Coding of Three Sustainability Reports:

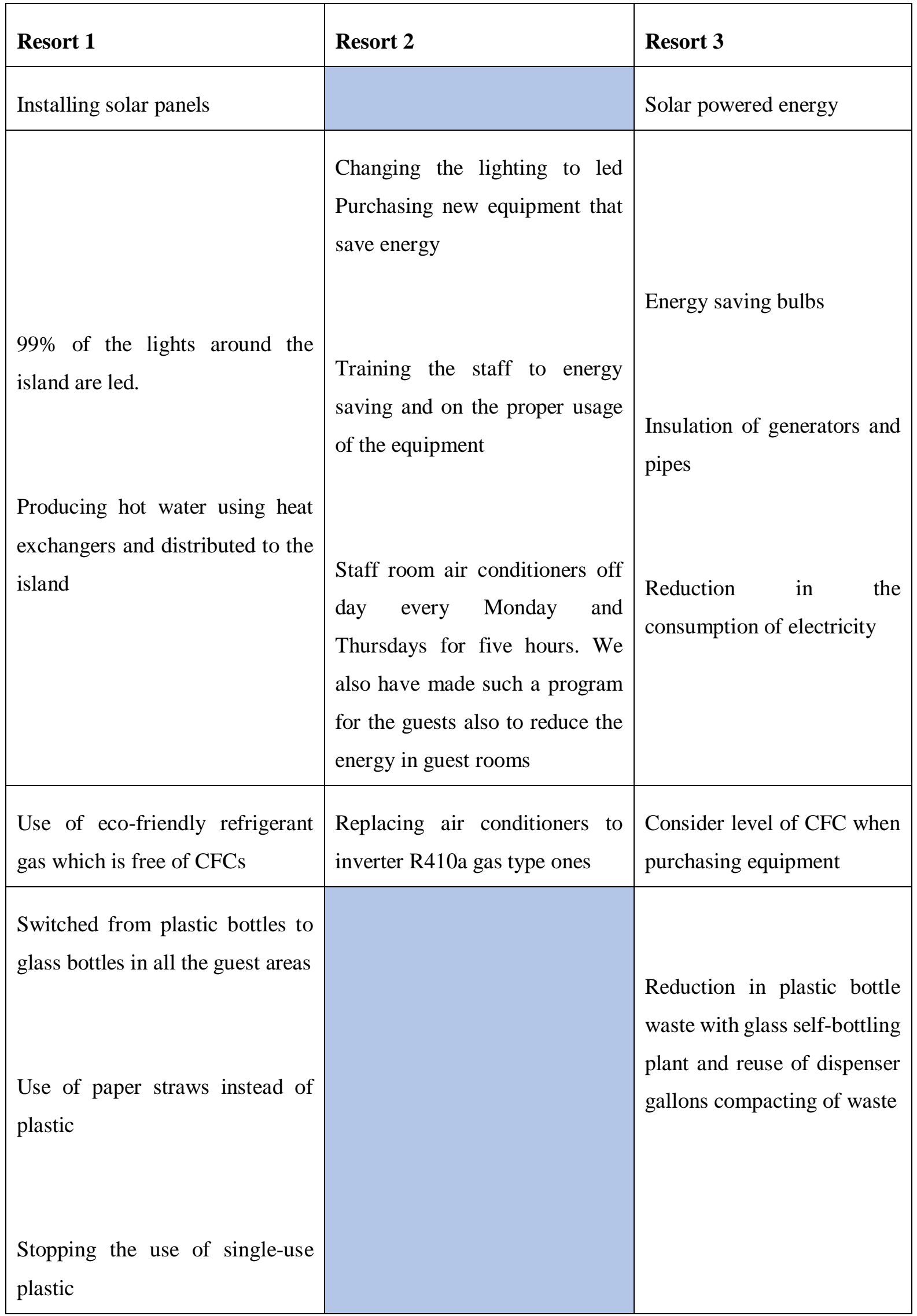




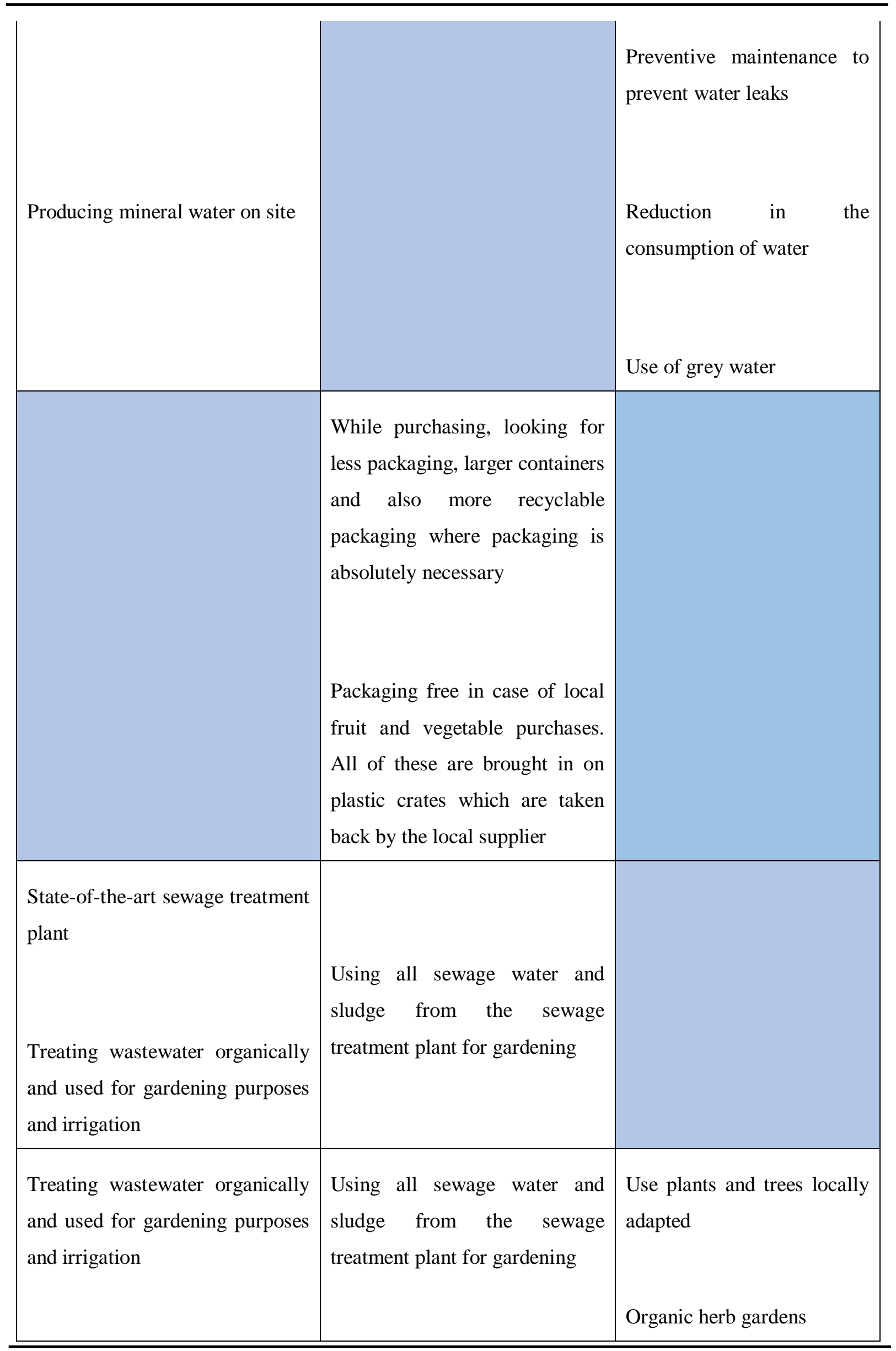




\begin{tabular}{|c|c|c|}
\hline $\begin{array}{l}\text { Grinding all the green waste } \\
\text { (dried leaves etc.) And using } \\
\text { them as mulch for soil } \\
\text { stabilisation }\end{array}$ & $\begin{array}{l}\text { Use some wastes from the trees } \\
\text { as fertilizers } \\
\text { Using organic fertilizers such as } \\
\text { coco peat and cow dung }\end{array}$ & $\begin{array}{l}\text { Removal of invasive plants } \\
\text { species }\end{array}$ \\
\hline & $\begin{array}{l}\text { Purchasing environmentally } \\
\text { friendly chemicals } \\
\text { Sending all of the chemical } \\
\text { wastes to Secure Bag, a licensed } \\
\text { company for collection and } \\
\text { recycling different types of } \\
\text { waste }\end{array}$ & $\begin{array}{l}\text { Use of eco-friendly cleaning } \\
\text { products use of eco-friendly } \\
\text { pesticides }\end{array}$ \\
\hline $\begin{array}{l}\text { Electric bikes and carts are used } \\
\text { for commute and baggage } \\
\text { transfer within the island }\end{array}$ & & \\
\hline $\begin{array}{l}\text { Set up of artificial reefs to help } \\
\text { boost the growth of coral reefs }\end{array}$ & & $\begin{array}{l}\text { Restoration and preservation } \\
\text { of coral reef program } \\
\text { Snorkeling activities to } \\
\text { understand } \\
\text { biodiversity } \\
\text { Ensure proper mooring of } \\
\text { boats to avoid damage by } \\
\text { anchor }\end{array}$ \\
\hline
\end{tabular}


Avoiding cutting down trees. If necessary, safely relocated to

Tree planting other parts of the island

Safely relocating of coral when jetty and breakwater constructed

Special programs with world environment day involving both hotel guests, staff and community, (e.g. Green Monthly activity along with staff talks, clean up, tree planting, and guests such as reef cleanups, tree planting, coral planting nature walks)

Special programs with earth hour involving both hotel guests and staff

Re-use towel and linen policy

Producing biogas as a by-product of organic waste and using cooking purpose

Sending untreated waste to Thilafushi, the designated island for waste management

Waste separation

Organic waste used for composting electronic waste management 
Use of a glass crusher, paper compactor and can crusher inhouse

$60 \%$ are locals, and all have the opportunity to work their way up the ladder

Senior management team which is also comprised of a majority of locals

Support the local community by purchasing the fish directly from the fishermen

While partnering with Parley, involving nearby local schools in their plastic waste management

Purchase of all cadjan what we use for roof thatching from local islands

Purchase of some vegetables and fruits from nearby island once a week

Donating some waste
management equipment to
nearby island
Guest and staff excursions to
nearby island regularly, which

Favor local goods to save on transport costs 


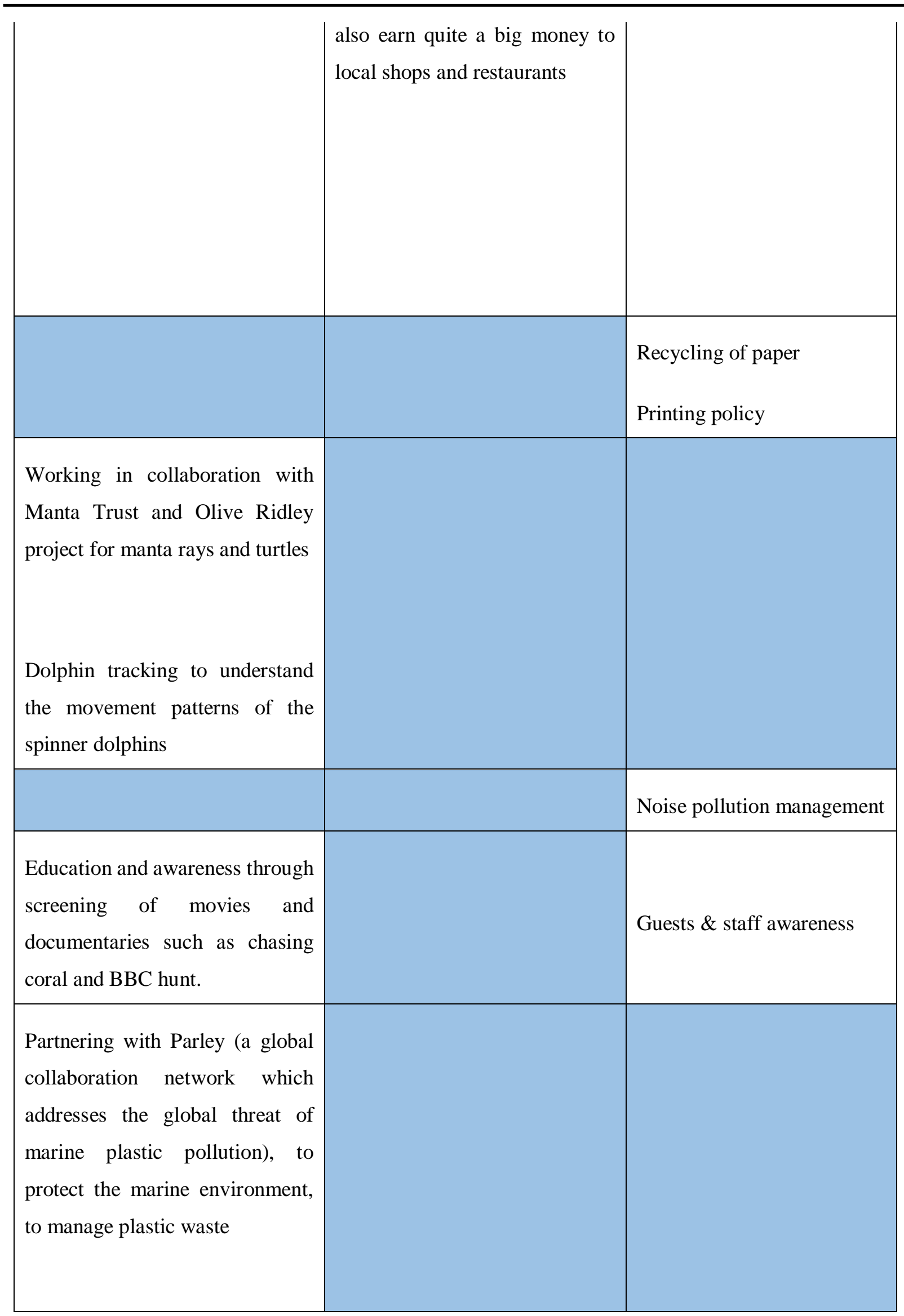


While partnering with Parley, involving nearby local schools in their plastic waste management 
